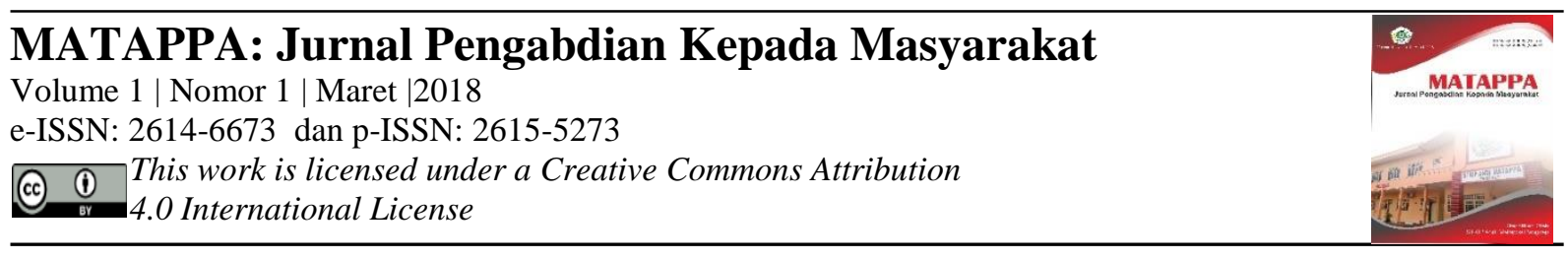

\title{
Sarjana (Sarana Belajar Anak Jalanan): Pemberdayaan Anak Jalanan Mandiri, Kreatif Dan Inovatif Melalui Pendidikan Kewirausahaan
}

\section{Fajri Basam $^{1)}$, Amri Amal' ${ }^{2)}$}

\section{Keywords : \\ Anak Jalanan; \\ Pendidikan non Formal; \\ Kewirausahaan. \\ Corespondensi Author \\ Fakultas Keguruan dan Ilmu \\ Pendidikan, Universitas \\ Muhammadiyah Makassar \\ Jalan Sultan Alauddin No. 259 \\ Talasalapang, Kota Makassar \\ *Email: basamfajri@gmail.com}

\section{History Artikel}

Received: 24-01-2018

Reviewed: $10-02-2018$

Revised: 02-03-2018

Accepted: 10-03-2018

Published: 30-03-2018

\begin{abstract}
ABSTRAK
Kota Makassar merupakan salah satu kota di indonesia yang tidak terlepas dari masalah anak jalanan. Anak jalanan merupakan kelompok sosial yang sangat rentan dari berbagai tindakan kekerasan baik fisik, emosi, seksual maupun kekerasan sosial. Maka dari itu melalui program pengabdian kepada masyarakat bermaksud ikut berperan aktif dalam menyelesaikan permasalahan anak jalanan melalui program "SARJANA (Sarana Belajar Anak Jalanan) : Pemberdayaan Anak Jalanan Mandiri, Kreatif, dan Inovatif Melalui Pendidikan Kewirausahaan". Luaran yang diharapakan dari program ini adalah mampunya menjadikan anak jalanan menjadi mandiri, kreatif dan inovatif dalam sehingga tidak lagi menjadi peminta-minta yang meresahkan masyarakat melalui pendidikan kewirausahaan dan pemberian keterampilan yang sesuai dalam jangka waktu yang relatif singkat. Metode Pelaksanaan yaitu: (1) pemberian materi kewirausahaan, (2) materi Manajemen Produksi dan Keuangan, (3) Materi Manajemen Pemasaran, (4) materi motivasi, (5) monitoring dan evaluasi. Hasil yang diperoleh dari pengabdian ini adalah anak binaan sudah memiliki kemampuan kreatif untuk memproduksi berbagai produk yang dapat menjadi bekal kedepannya untuk menjadi mandiri.
\end{abstract}

\section{PENDAHULUAN}

Anak jalanan merupakan salah satu masalah sosial yang sangat kompleks di Indonesia. Berdasarkan Kementerian Sosial pada 2015, jumlah anak jalanan di Indonesia tercatat sebanyak 33.400 jiwa yang tersebar di 16 provinsi (Kompas, 2017). Dengan jumlah yang sangat banyak menjadikan anak jalanan tersebut sulit untuk diatasi.

Beberapa ahli berpendapat bahwa anak jalanan merupakan anak yang memiliki umur di bawah 18 tahun yang memnghabiskan sebagian besar hidupnya di jalanan untuk memenuhi kebutuhan ekonominya. Secara umum ciri-ciri anak jalanan adalah: (1) Berada di tempat umum (jalan pasar, pertokoan, tempat-tempat hiburan) selama 3-24 jam sendiri. (2) Berpendidikan rendah (kebanyakan putus sekolah, sedikit sekali yang tamat SD). (3) Berasal dari keluargakeluarga tidak mampu (kebanyakan kaum urban, beberapa diantaranya tidak jelas keluarganya). 4) Melakukan aktivitas ekonomi (melakukan pekerjaan pada sektor informal).

Kota Makassar merupakan salah satu kota di indonesia yang tidak terlepas dari masalah anak jalanan. Menurut Dinas Sosial Kota Makassar sepanjang tahun 2017 sebanyak 1000 anak jalanan terjaring razia (Pasakai, 2017). Kehadiran anak jalanan di kota Makassar merupakan sesuatu yang sangat dilematis. Di satu sisi mereka dapat mencari nafkah dan 
mendapatkan pendapatan (income) yang dapat membuatnya bertahan hidup dan menopang kehidupan keluarganya. Namun di sisi lain kadang mereka juga berbuat hal-hal yang merugikan orang lain, misalnya berkata kotor, mengganggu ketertiban jalan, merusak body mobil dengan goresan dan lain-lain. Selain itu permasalahan anak jalan juga adalah sebagai objek kekerasan.

Tempat-tempat favorit anak jalan untuk beraktifitas yaitu tempat umum yang ramai seperti perempatan jalan, mall, mini market, dan mesjid-mesjid raya. Anak jalanan yang ditemui di Kota Makassar biasanya mencari uang di jalanan dengan melakukan aktivitas tertentu seperti mengamen, mengemis, berjualan koran, mengatur mobil belok (Polisi Pak Ogah), tukang parkir, mendatangi ruko-ruko, kampus atau tempat umum lainnya sambil menawarkan buku kumpulan doa-doa atau stiker ayat kursi, mengelap kendaraan di pertamina, dan lainlainya.

Anak jalanan merupakan kelompok sosial yang sangat rentan dari berbagai tindakan kekerasan baik fisik, emosi, seksual maupun kekerasan sosial. Menurut Anasiru (2011), anak jalanan mudah terkontaminasi dengan prilaku negatif orang dewasa di jalan (preman).

Kecenderungan semakin meningkatnya jumlah anak jalanan merupakan fenomena yang perlu segera ditingkatkan penanganannya secara lebih baik, sebab jika permasalahan tidak segera ditangani maka dikhawatirkan menimbulkan permasalahan sosial baru. Situasi dan kondisi jalanan sangat keras dan membahayakan bagi kehidupan anak-anak, seperti ancaman kecelakaan, eksploitasi, penyakit, kekerasan, perdagangan anak, dan pelecehan seksual.

Informasi yang didapatkan dari media online menyebutukan bahwa salah satu kendala dinas sosial kota Makassar untuk membina anak jalanan adalah sarana dan prasarana yang tidak memadai sehingga sulit karena tidak memiliki penampungan untuk melakukan rehabilitasi atau karantina (Zulkifli, 2018). Tentunya permasalaha sosial seperti anak jalanan tidak bisa hanya dibebankan kepada salah satu instansi pemerintah, tetapi seluruh elemen masyarakat harus bekerja sama untuk ikut berpartisipasi dalam menyelesaikan suatu permasalahan.

Melihat permasalahan di atas, diperlukan pemikiran-pemikiran yang kreatif dan inovatif untuk dapat menyelesaikan permasalahan tersebut. Maka dari itu melalui program pengabdian kepada masyarakat bermaksud ikut berperan aktif dalam menyelesaikan permasalahan anak jalanan melalui program "SARJANA (Sarana Belajar Anak Jalanan) : Pemberdayaan Anak Jalanan Mandiri, Kreatif, dan Inovatif Melalui Pendidikan Kewirausahaan".

Menurut Hidayat, dkk (2017), salah satu penyebab munculnya anak jalanan adalah faktor ekonomi. Dan untuk menanggulangi permsalahan anak jalanan perlu dilakukan pemantapan ekonomi (Purwaningsih,

Luaran yang diharapakan dari program ini adalah mampunya menjadikan anak jalanan menjadi mandiri, kreatif dan inovatif dalam sehingga tidak lagi menjadi peminta-minta yang meresahkan masyarakat melalui pendidikan kewirausahaan dan pemberian keterampilan yang sesuai dalam jangka waktu yang relatif singkat.

\section{METODE}

\section{Tahap persiapan}

a) Diskusi

Kegiatan ini dilakukan oleh semua anggota tim pelaksana secara musyawarah mufakat. Dalam kegiatan ini: (1) tim merancang konsep program, (2) pencarian lokasi sasaran yang tepat, (3) penjadwalan program yang terdiri atas tahap persiapan, pelaksanaan program dan penyusunan laporan, dan (4) diskusi tentang pelaksanaan program. Hal ini dilakukan agar proses kegiatan dapat berjalan sistematis dan lancar.

b) Peninjauan Lokasi

Kegiatan ini meliputi: (1) konsultasi dengan pejabat kelurahan setempat, (2) mendatangi lokasi sasaran program sesuai dengan rekomendasi pejabat kelurahan setempat, (3) diskusi dengan ketua RW, sekertaris RW, Ketua PKK, dan warga setempat, (4) survei kondisi dan potensi wilayah dari segi fisik, sosial, ekonomi, maupun lingkungan warga setempat.

c) Pemilihan Produk dan Survei Pasar

Semua anggota kelompok mencari informasi dan selanjutnya berdiskusi untuk menentukan produk yang akan digunakan dalam pelaksanaan program dan melakukan survei pasar atas produk tersebut. Kemudian kelompok mencari informasi, mempelajari, serta mempraktekkan cara membuat produk tersebut.

\section{Tahap Pelaksanaan Program}

a) Sosialisasi 
Kegiatan ini meliputi mensosialisasikan gambaran konsep dan jadwal pelaksanaan program yang akan dilaksanakan. Hal ini dimaksudkan agar partisipasi warga dalam program ini bisa berlangsung secara berkesinambungan. Selain itu agar ada feedback dari masyarakat seputar masalah teknis pelaksanaan nantinya. Dalam tahap ini dimaksudkan agar terjadinya kerjasama antara pelaksana program dan warga.

b) Pendidikan Kewirausahaan

Kegiatan ini berupa diklat non-formal yang terdiri dari:

Materi Kewirausahaan. Dalam kegiatan ini diberikan pemahaman dasar mengenai prinsip-prinsip entrepreneur, cara menjadi entrepreneur yang baik, strategi memulai usaha, dan mengelolanya hingga menikmati hasilnya.

Materi Manajemen Produksi dan Keuangan. Dalam kegiatan ini diberikan pengetahuan dasar mengenai cara memproduksi suatu barang/produk dari mulai bahan baku hingga menjadi produk jadi, penyusunan anggaran biaya produksi, penghitungan biaya produksi yang dibutuhkan untuk memproduksi barang per unit, serta membuat laporan produksi sederhana. Dalam materi ini juga diberikan pengetahuan bagaimana menghitung keuntungan yang diharapkan dari hasil penjualan yang telah dilakukan serta meminimalisir risiko kerugian.

Materi Manajemen Pemasaran. Materi ini untuk memberikan pengetahuan dasar caracara memasarkan produk secara efektif dan tepat sasaran.
Materi Motivasi. Materi ini diberikan kepada para peserta agar mereka termotivasi untuk terus maju, pantang menyerah dan berinovasi.

c) Monitoring dan Evaluasi

Kegiatan ini dilakukan untuk memantau perkembangan program yang telah dilaksanakan, jika terjadi suatu kendala dalam pelaksanaan program, maka dapat segera diselesaikan. Sedangkan kegiatan evaluasi dilakukan untuk memyempurnakan tahap pelaksanaan program selanjutnya.

\section{HASIL DAN PEMBAHASAN}

Tahap pertama pelaksaan program SARJANA dilakukan dengan memberikan penguatan materi kewirausahaan dan motivasi kepada masyarakat sasaran agar proses praktik dari program ini mampu berjalan seperti apa yang diharapkan. Pelaksanaan program ini dilaksanakan dengan bekerjasama dengan masyrakat sekitar. Peran masyarakat yaitu dengan memberikan dukungan moril dan fasilitator akomodasi. Pembekalan materi kepada masyarakat sasaran dilakukan dengan secara non formal dengan pendekatan pembelajaran menyenangkan agar anak-anak peserta progam tidak bosan dalam menerima materi. Proses pelaksanaan materi ini sendiri dengan memanfaatkan tempat tinggal masyarakat dan tempat ibadah seperti mushollah. Proses pemberian materi kewirausahaan dan motivasi seperti yang ditunjukkan pada Gambar 1.
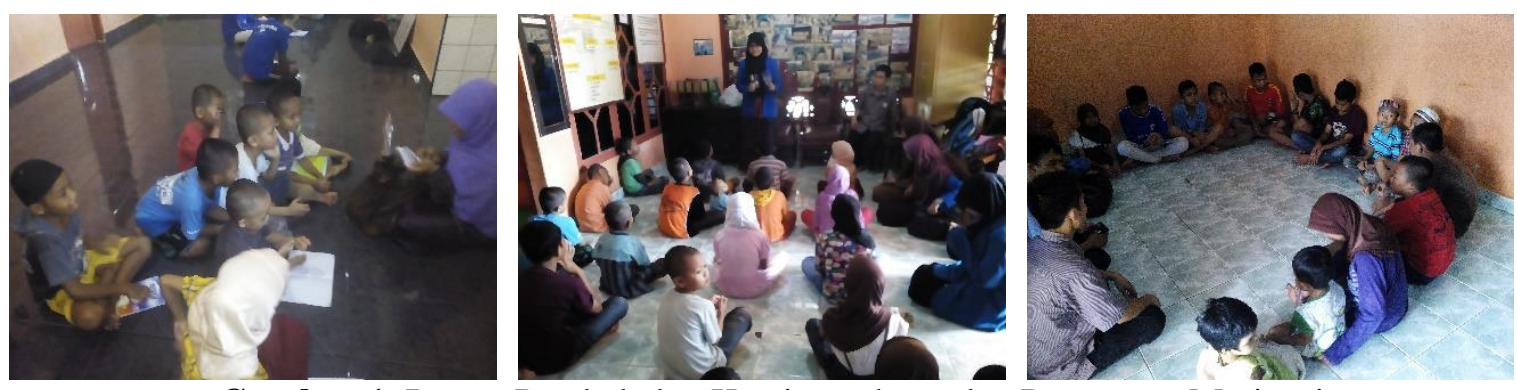

Gambar 1. Proses Pembekalan Kewirausahaan dan Penguatan Motivasi

Program ini memberikan dampak positif terhadap anak jalanan karena mampu meningkatkan keterampilan, kemandirian, kreatifitas, dan inovatif pada anak binaan. Selain itu juga membuka wawasan atau cakrawala berfikir anak-anak mengenai pembuatan produk kerajinan kain flannel dengan berbagai macam kreasi. Awalnya bentuk kerajinan yang dibuat hanya gantungan kunci dan bros, namun sampai pada perkembangan saat ini terus mengalami peningkatan dan terus berlatih dan berwirausaha dengan bentuk yang lebih menarik. Bukan hanya gantungan kunci tapi juga tempat pulpen, toples hias, lukisan gantung,dan lain sebagainya yang terbuat dari kardus bekas yang dihiasi dengan kain flanel seperti yang ditunjukkan Gambar 2. 

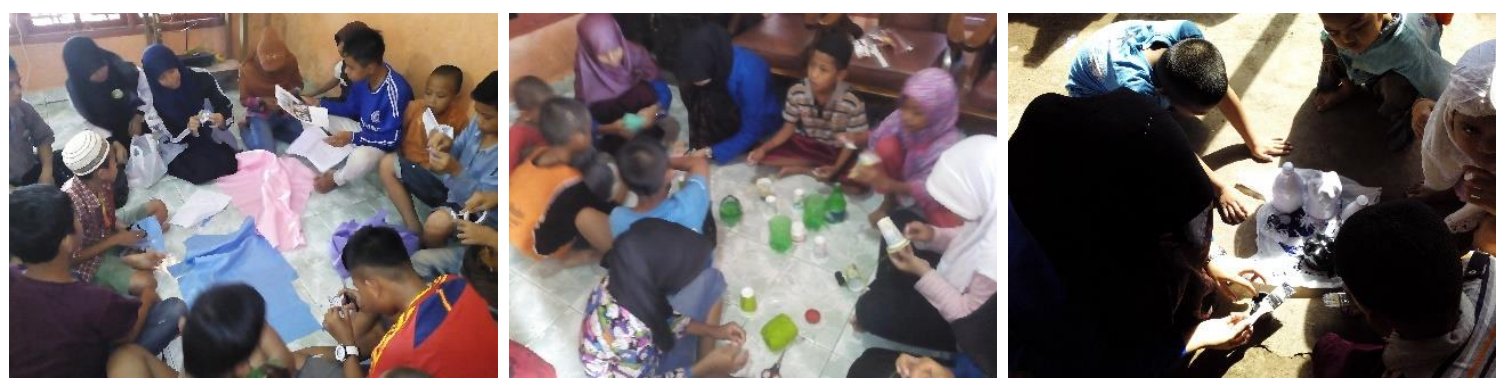

Gambar 2. Praktik Pembuatan Produk Kewirausahaan

Berbagai macam produk dengan kreasi yang beragam ini dapat melatih jiwa kewirausahaan bagi anak binaan sehingga dapat meminimalisir kegiatan yang menjadi kebiasaannya yaitu mengamen dan mengemis di jalan yang membuat resah masyarakat. Program sarana belajar anak jalanan melalui pendidikan wirausaha yang direncanakan berjalan dengan baik, meskipun proses pemasaran dari hasil pelatihan tersebut belum maksimal karena masih dalam tahap pemantapan pelatihan pembuatan produk.
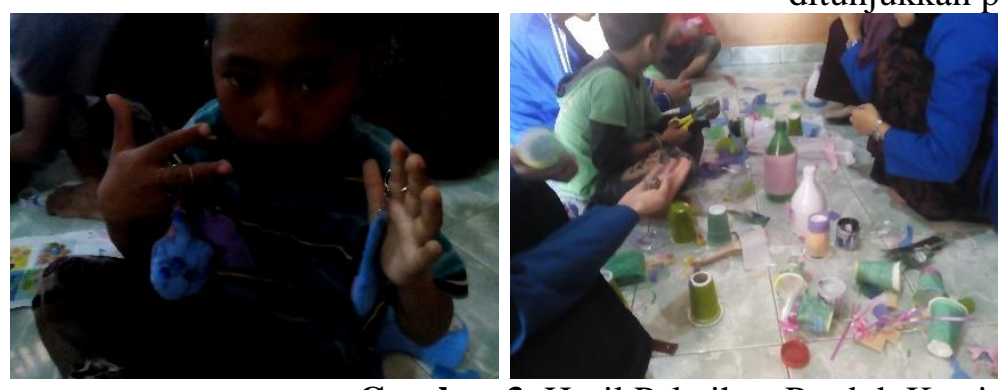

Pembuatan produk yang lebih bermutu membuat para anak binaan lebih semangat dan sungguh-sungguh untuk berlatih dan berkreasi menghasilkan produk kewirausahaan. Program ini terlihat mampu mengurangi dampak potensi terjadinya penyimpangan sosial di masyarakat karena adanya kesibukan dan kegiatan lain yang dilakukan, serta membuat anak lebih terampil dan inovatif. Kegiatan ini juga dapat mengasah kreatifitas dari anak binaan shingga dapat menjadikan mandiri secara ekonomi. Salah satu contoh produk yang dihasilkan seperti yang ditunjukkan pada Gambar 3.

Gambar 3. Hasil Pelatihan Produk Kewirausahaan

Menurut Putra, dkk (2016), pemberdayaan dapat menjadikan anak jalan mendapatkan kehidupan yang lebih layak dan prilaku positif sesuai norma dan etika yang berlaku dalam masyarakat. Program-program pemberdayaan seperti harus mendapatkan dukungan dari berbagai kalangan sehingga keberadaannya tidak hanya sesaat akan tetapi mampu jalan secara berkesinambungan.

Adapun rencana tahap berikutnya dalam program ini setelah melakukan pelatihan pembuatan produk siap jual, maka akan dilakukan berbagai kerjasama penjualan produk yang dibuat oleh anak-anak tersebut yang akan dipasarkan pada beberapa tempat, yaitu pada toko-toko dan pemasaran melalui sosial media. Kemudian mencari wadah penjualan dan tempat pelatihan atau pembuatan produk yang lebih baik sehingga dapat meningkatkan produk yang lebih inovatif, sehingga menghasilkan kreatifitas yang lebih bermutu dan diminati oleh pengunjung atau masyarakat pada umumnya.

\section{SIMPULAN DAN SARAN}

Dapat disimpulkan bahwa Sarana Belajar Anaka Jalanan ini memiliki manfaat yang cukup banyak selain memberikan keterampilan berwirausaha hal ini juga menjadi sekolah nonformal bagi anak jalanan yang pada dasarnya merupakan anak putus sekolah, sehingga hal ini merupakan salah satu wadah untuk menjadikan anak-anak putus sekolah memiliki harapan menata masa depan mereka yang lebih baik.

Adanya contoh Sarana belajar Anak Jalanan ini disarankan agar bisa menjadi motivasi didaerah-daerah lainya untuk disiapkan wadah yang seperti ini untuk anak-anak yang putus sekolah. 
Anasiru, R. (2011). Implementasi Model-Model Kebijakan penanggulangan Anak Jalanan Di Kota Makassar. Jurnal Sosiokonsepsia, 16, 175-186. Diakses dari http://www.academia.edu/download/3518 5152/c917d9ef5b505a821d1a82ce799b1e 5a.pdf.

Hidayat, M. A., Anwar, A., \& Hidayah, N. (2017). Pendidikan Non Formal Dalam Meningkatkan Keterampilan Anak Jalanan. Journal Edudeena, 1(1). Diakses dari

http://jurnal.stainkediri.ac.id/index.php/ed udeena/article/view/445/281.

Kompas. 2017. Mensos Optimis "Indonesia Bebas Anak Jalan" Terealisasi Tahun Ini. Kompas.com - 11/02/2017, 22:38 WIB. Diakses dari http://regional.kompas.com/read/2017/02/ 11/22380161/mensos.optimistis.indonesia bebas.anak.jalanan.terealisasi.tahun.ini

Pasakai, M. A. 2017. Dinsos Telah Amankan Seribu Anak Jalanan di Makassar, Tapi.. Diakses dari https://www.sulselsatu.com/2017/07/29/m akassar/dinsos-telah-amankan-seribuanak-jalanan-di-makassar-tapi.html.
Purwaningsih, E. (2015). Kajian Terhadap Potensi Anak Jalanan Dan Masyarakat Pedongkelan Pulogadung Jakarta Timur Dalam Rangka Peningkatan Mutu Kehidupan Dan Kesadaran Hukum Masyarakat (Suatu Penelitian Pemberdayaan). ADIL: Journal of Law, 4(1), 123-149.

Putra, F., Hasanah, D., \& Nuriyah, E. (2016). Pemberdayaan Anak Jalanan di Rumah Singgah. SHARE: Social Work Journal, 5(1), 51-64. Diakses dari http://fisip.unpad.ac.id/jurnal/index.php/s hare/article/view/53.

Zulkifili, S. 2017. Kenapa Anak Jalanan Susah Ditertibkan? Ini Alasan Dinas Sosial Makassar. Rakyatku.com. Diakses dari http://news.rakyatku.com/read/35298/201 7/01/17/kenapa-anak-jalanan-susahditertibkan-ini-alasan-dinas-sosialmakassar. 